\title{
SAWING SMALL LOGS
}

\section{BY C. F. MCBRIDE ${ }^{1}$}

The term small log has a different meaning in each of the lumbering areas of Canada. In Eastern Canada studies made by Doyle (1) show that the average spruce and jackpine saw-log is between 7 and 8 inches and the average balsam is about 6 inches top diameter. In the interior of British Columbia studies show that the average $\log$ is between 12 and 13 inches and experience on the coast suggests a considerably larger average log between 18 and 20 inches. In this paper logs under 12 inches top diameter are considered to be small.

In British Columbia and Alberta the size of logs cut in sawmills is decreasing. The shortage of timber in many areas has made it necessary to log stands such as lodgepole pine that formerly were considered too small. Utilization standards are improving so that logs are utilized down to smaller top diameters. Plywood plants are now using many of the larger logs leaving the smaller logs for the sawmills.

As a result of this trend, many mills built for a run of larger logs are faced with increased costs. On the other hand, mills are now being built specially to cut small logs either in connection with a standard mill or as a separate unit where the timber is uniformly small. As yet no typical sawmill either for large or small logs has been developed. However, there has been a very definite trend to automation and mechanization and small logs are well suited to this.

Small logs require special handling from the standing tree right through the sawmill. However, the effect of log size on logging costs and methods has been studied by many workers and is considered outside the scope of this paper.

Because so many factors are involved in determining the ideal mill it is not suggested that any special type of sawmill is best suited to saw small logs. However, a discussion of the results of studies made at several types of mills will show how small logs affect (1) production rates, (2) lumber sizes, (3) lumber values, (4) lumber recovery factors and (5) the amount of sawmill residues.

Certain features of the following types of sawmills will be discussed:

1. Circular head-saw and edger.

2. Circular head-saw, oscillating gang circular re-saw and edger.

3. Circular head-saw, oscillating gang and edger.

4. Circular head-saw, line-bar band re-saw and edger.

5. Circular head-saw, circular re-saw and edger.

6. Band head-saw, oscillating gang and edger.

7. Scrag mill, bull edger and circular re-saw.

8. Scrag mill and bull edger.

\footnotetext{
${ }^{2}$ Research Officer, Vancouver Laboratory, FPRB. Department of Forestry of Canada, Forest
} Products Research Branch. Contribution No. P-5. 


\section{Production Rates}

When handling small logs in a sawmill the problem is essentially one of logistics or materials handling.

One thousand board feet of lumber is produced from the following number of logs in each of the diameter classes.

\begin{tabular}{cc}
$\begin{array}{c}\text { Diameter Class } \\
\text { Top Diameter inches }\end{array}$ & $\begin{array}{c}\text { No. of } 16 \text {-foot logs to produce } \\
\text { I M ft.b.m. of lumber }\end{array}$ \\
\hline 6 & 40 \\
9 & 17 \\
12 & 10 \\
15 & 7 \\
\hline
\end{tabular}

Thus a mill cutting $50 \mathrm{M}$ ft. b.m. in 8 hours would require 2000 logs with 6-inch tops but only $500 \mathrm{logs}$ with 12-inch tops and 350 15-inch logs.

Actual sawing times recorded in a band mill with a cant gang show a comparison of headrig times for live sawing and sawing cants for the gang.

From Table 1 it can be seen that cutting cants from small logs for a gang results in a time saving of 25 per cent for logs with 7 -inch top but a saving of 51 per cent for 12-inch logs.

TABLE 1

A Comparison of the Sawing Time at the Headrug for Cutting Cants and for Cutting Logs Alive

\begin{tabular}{cccc}
\hline \multirow{2}{*}{$\begin{array}{c}\text { Log Top } \\
\text { Dismeter }\end{array}$} & \multicolumn{2}{c}{$\begin{array}{c}16^{\prime} \text { Logs only } \\
\text { Total Sawing Time-min./log }\end{array}$} & $\begin{array}{c}\text { \% Reduction } \\
\text { in Time When } \\
\text { Sowing Cants }\end{array}$ \\
\hline & No Cants & Cants & - \\
6 & .77 & - & 25 \\
7 & .82 & .62 & 30 \\
8 & .92 & .64 & 37 \\
9 & 1.04 & .66 & 41 \\
10 & 1.19 & .70 & 46 \\
11 & 1.36 & .73 & 51 \\
12 & 1.54 & .76 & \\
\hline
\end{tabular}

Sawing times for small logs are as in Table 2 for a typical small circular mill cutting about 25 to $30 \mathrm{M}$ ft. b.m. per 8 hours from 16 -foot spruce logs and employing 9 men from the log deck to the green chain.

The sawing time per $M$ ft.b.m. for 6 -inch logs is $2 \frac{1 / 2}{2}$ times greater than for 12 -inch logs. In this mill the best production rate was achieved on 15.5-inch logs. 
TABLE 2

Sawing Time for a Circular Mill Cutting 25 To 30 M. FT.B.M. LUmber TAlly PER 8 Hours

\begin{tabular}{cccc}
\hline $\begin{array}{c}\text { Top } \\
\text { Diameter }\end{array}$ & $\begin{array}{c}\text { Minutes } \\
\text { per Log }\end{array}$ & $\begin{array}{c}\text { Minutes } \\
\text { per M ft.b.m. } \\
\text { Lumber Tally }\end{array}$ & $\begin{array}{c}\text { Man-hours } \\
\text { pex M ft.b.m. }\end{array}$ \\
\hline 6 & 0.8 & 33.7 & 5.6 \\
7 & 0.8 & 28.3 & 4.7 \\
8 & 0.9 & 23.3 & 3.9 \\
9 & 1.0 & 20.2 & 3.4 \\
10 & 1.1 & 17.3 & 2.9 \\
11 & 1.2 & 15.2 & 2.5 \\
12 & 1.3 & 13.9 & 2.3 \\
13 & 1.5 & 13.1 & 2.2 \\
14 & 1.7 & 12.7 & 2.1 \\
15 & 1.9 & 12.5 & 2.1 \\
16 & 2.2 & 12.5 & 2.1 \\
17 & 2.5 & 12.7 & 2.1 \\
18 & 2.9 & 13.1 & 2.2 \\
19 & 3.2 & 13.5 & 2.2 \\
\hline
\end{tabular}

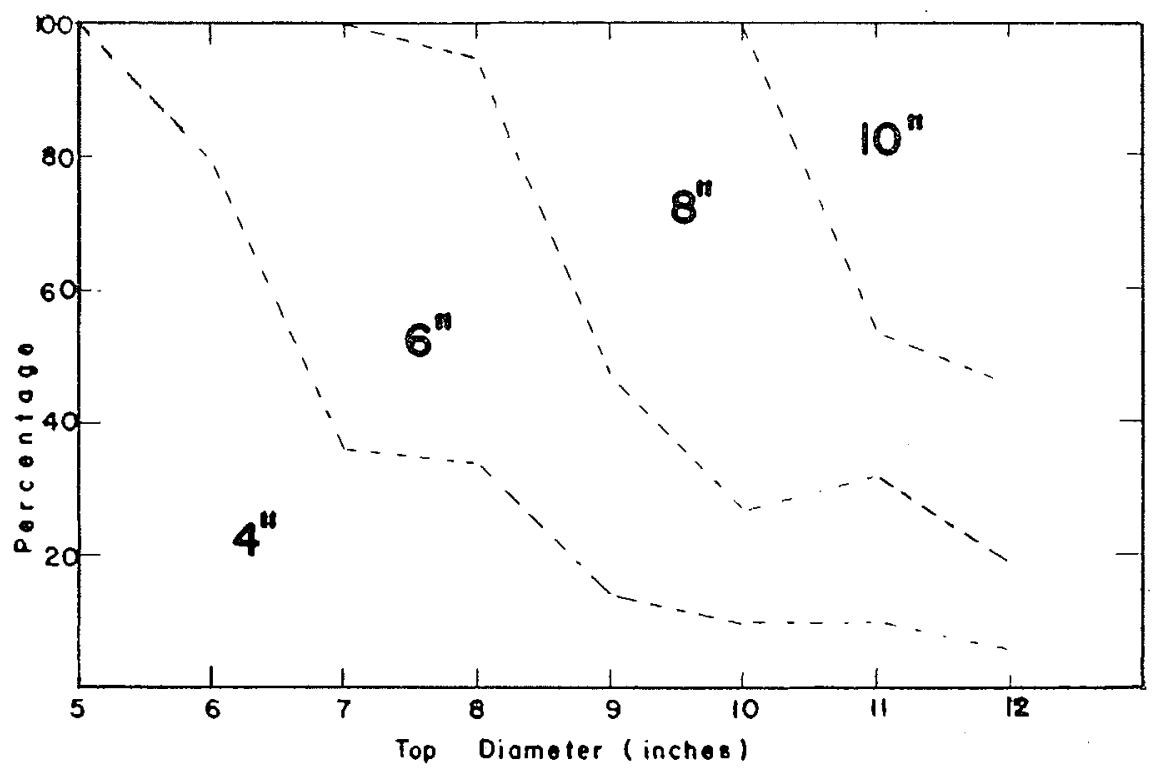

FIGURE 1. Distribution of lumber widths by $\log$ size. 


\section{LUMBER SIZES}

The chart in Figure 1 illustrates the distribution of lumber widths that develop when cutting small logs. These figures must be considered only as indicative of what may be obtained as market conditions and mill order files also affect to some extent the widths obtained. However, it can be assumed that in the smaller diameters the sawyer will try to get as wide a piece as possible.

\section{Lumber Grade ReCovery}

The grade of lumber that is sawn depends on so many factors such as species, site, density of stocking, age, size of branches and sawyer's ability, etc., that it is difficult to generalize about the grades that will be recovered from small logs. Usually logs below 12 inches top diameter produce no clear lumber. If the logs come from small trees and the knots are sound and not too large these logs yield a high percentage of the better grades of construction lumber such as No. 2 and Better and No. 3 in the Western Pine Association board grades. The amounts of No. 4 and 5 Common are usually about 10 per cent.

Table 3 shows grade recoveries for western white spruce and for lodgepole pine $\operatorname{logs}$ cut from small trees.

TABLE 3

Lumber Grade Recoveries by log Diameter Classes W.P.A. Grades For Boards

\begin{tabular}{|c|c|c|c|c|c|c|c|c|}
\hline & \multicolumn{8}{|c|}{ Small Western White Sprace Logs } \\
\hline & 6 & 7 & 8 & 9 & 10 & 11 & 12 & 13 \\
\hline Clear & - & - & - & - & 1 & 4 & 5 & 2 \\
\hline \#2 \& Btr. & 63 & 70 & 69 & 63 & 45 & 60 & 59 & 69 \\
\hline \#3 Common & - & 15 & 8 & 12 & 9 & 3 & 11 & 15 \\
\hline \#4 $\quad "$ & - & 13 & 20 & 19 & 42 & 31 & 22 & 13 \\
\hline \multirow[t]{2}{*}{$\# 5$} & 37 & 2 & 3 & 6 & 3 & 2 & 3 & 1 \\
\hline & \multicolumn{8}{|c|}{ Lodgepole Pine } \\
\hline Clear & - & - & - & 一 & - & - & - & 6 \\
\hline \#2 \& Btr. & 51 & 38 & 57 & 41 & 42 & 29 & 45 & 35 \\
\hline \#3 Common & 41 & 55 & 41 & 54 & 48 & 59 & 49 & 44 \\
\hline \#4 " & 8 & 7 & 2 & 5 & 10 & 12 & 6 & 15 \\
\hline \#5 & - & - & - & - & - & - & - & - \\
\hline
\end{tabular}

When the small logs are the tops of large trees the number and size of knots is usually enough to make the boards run heavily to No. 3 Common. In the larger logs from these trees the percentages of No. 2 and Better and No. 4 Common increase with decrease in diameter and at the same time the percentage of No. 3 Common decrease (Table 4). 
TABLE 4

Spruce Lumber Grade Recovery from Normal Stzed LoGS Shown as a Percentage by Grade in 3-inch Diameter Classes

\begin{tabular}{|c|c|c|c|c|c|c|c|}
\hline \multirow{2}{*}{ Lamber Grades } & \multicolumn{7}{|c|}{ Diameter Class } \\
\hline & 6 & 9 & 12 & 15 & 18 & 21 & $\sqrt{24}$ \\
\hline D \& Btr. Clear & - & - & 1 & 1 & 2 & 3 & 6 \\
\hline \#2 \& Btr. Com. & 9 & 21 & 25 & 26 & 24 & 20 & 14 \\
\hline \#3 Common & 84 & 73 & 68 & 66 & 63 & 62 & 62 \\
\hline \#4 Common & 7 & 6 & 6 & 7 & 10 & 15 & 18 \\
\hline \#5 Common & 一 & - & - & 一 & 1 & - & - \\
\hline Total & 100 & 100 & 100 & 100 & 100 & 100 & 100 \\
\hline
\end{tabular}

\section{LUMBER RECOVERY FACTOR}

The lumber recovery factor, the board feet of lumber produced per cubic foot of $\log$, is low in the smaller diameters. It increases quite rapidly to 9 inches and from there increases more gradually to the larger diameters. Table 5 shows the lumber recovery factors for different mill types. All lumber volumes are based on 1-inch boards.

A study of this table serves to prove the point that the lumber recovery factor is a variable measure. Mill type, log size, lumber thickness, sizes cut and management policy all affect the recovery. Mills 1,3 , and 6 were mills cutting a fairly large average $\log$, and as a result the small logs were processed as quickly as possible with the emphasis on speed rather than recovery with the result that the lumber recovery factor is low for the small logs. In mills 2, 4, 5, 7 and 8 the run of logs was small and the emphasis was on recovery, with the result that the yield from small logs in these mills was higher than in the former group. Mill 8 was a stud mill and because it cut 8 -foot logs, showed a good lumber recovery factor. It is interesting to note the high factor of 7.3 obtained for 5 -inch logs which produce two $2 \times 4$ 's with very little waste.

Mill No. 2, which had a circular resaw in addition to the cant gang obtained a higher than average recovery for all $\log$ sizes, but the difference in recovery between $\log$ diameters is still evident. 


\section{SAWMILl Residue}

Log size has very little effect on the percentage of log volume made into sawdust. Studies show that 20 per cent of the volume of 6-inch logs, or 18 per cent of 15-inch logs, is made into sawdust.

The solid residue in the form of slabs, edgings and trim amounts to 34 per cent of 6-inch logs and 20 per cent of 15-inch logs.

It is from this solid residue that pulp chips are made and it is obvious that the volume of chips produced will vary with the size and quality of the logs sawn. In Table 6 the solid residue figures for spruce are converted to bone-dry units per $\mathrm{M}$ ft.b.m. lumber tally and oven-dry tons per $\mathrm{M}$ ft.b.m. lumber tally. If the same residue figures and lumber recovery were used for Douglas fir the oven-dry tons per $M$ ft.b.m. would be approximately 25 per cent greater because of its higher specific gravity.

TABLE 6

Showing Volume of Sawdust and Solid Residue Produced When

Spruce logs are Sawn into lumber on a Circular Mill and the Volume of Pulp Chips Per M fT.B.M. Lumber Tally

\begin{tabular}{ccccc}
\hline $\begin{array}{c}\text { Top } \\
\text { Diam. }\end{array}$ & $\begin{array}{c}\text { Sawdust } \\
\text { per 100 cu. ft. } \\
\text { Log Scale }\end{array}$ & $\begin{array}{c}\text { Solid Residue } \\
\text { per 100 cu, ft. } \\
\text { Log Scale }\end{array}$ & $\begin{array}{c}\text { Bone-dry Units } \\
\text { per M ft.b.m. } \\
\text { Lumber Tanly }\end{array}$ & $\begin{array}{c}\text { Oven-dry Tons } \\
\text { per M It.b.m. } \\
\text { Lumber Tally }\end{array}$ \\
\hline 6 & 20 & 34 & 0.61 & 0.72 \\
7 & 20 & 33 & 0.58 & 0.70 \\
8 & 20 & 32 & 0.56 & 0.67 \\
9 & 20 & 30 & 0.54 & 0.63 \\
10 & 19 & 28 & 0.48 & 0.58 \\
11 & 19 & 26 & 0.43 & 0.52 \\
12 & 19 & 24 & 0.38 & 0.46 \\
13 & 18 & 23 & 0.35 & 0.43 \\
14 & 18 & 21 & 0.31 & 0.37 \\
15 & 18 & 20 & 0.29 & 0.35 \\
\hline
\end{tabular}

\section{Discussion}

From the foregoing information it is obvious that sawing lumber from small logs in a conventional sawmill has several disadvantages, namely: a low rate of production, a lower yield, and a high percentage of narrow widths. On the other hand there is a higher recovery of pulp chips from the solid residues and a trend to better grades of common lumber. Also the fact that no clear lumber is produced makes these logs suitable for automation.

The problem of sawing small logs is one on which many have worked and there are several different solutions. The basic problem is materials handling in which a large number of small logs must be moved.

There are mills in the interior of British Columbia that operate successfully on logs with average diameters of 8 and 10 inches. By adopting efficient 
methods and automating as much as possible the mills can make a profit. There seem to be two broad approaches to the small log problem. One is to design and operate a specialty mill for small logs only, and the other is to relieve the conventional mills of small logs by adding a special mill to cut them. In this way the conventional mill operates more efficiently and the special mill should be efficient. This latter principle has been practised for years by the large coast mills where they have pony mills and round-log gang mills to cut the smaller logs in order to achieve a greater production rate on the main head-rig.

Studies in the interior areas of British Columbia have shown that high lumber recoveries from small logs were obtained from three types of mills: (1) Circular head-saw and line-bar band resaw, (2) Circular head-saw, oscillating cant gang and circular resaw, (3) Circular head-saw and circular resaw, both with narrow kerf. A mill with a band head-saw and oscillating cant gang sawing 1 -inch lumber gave high recovery for logs over 9 inches but processed the small logs as quickly as possible with recovery secondary. This is typical of the approach of the conventional mill to small logs.

It should be emphasized that cutting small logs efficiently can be achieved only by planning and fitting the right type of machinery to the job. In the three mills cited the lumber was well manufactured and sizes were accurate. Poor sawing practices and inaccurate sizing cause much greater losses in small than in large logs.

In an area where pulp chips can be marketed perhaps the emphasis should be on rate and accuracy of sawing rather than on maximum recovery when small logs are handled.

In calculating profit margins many different methods may be followed but if the net profit to the sawmill is to be considered then the procedure should be to make the best part of the small logs into lumber and chip the rest rather than chip the whole log. Two recent developments indicate that this could be a very profitable approach. A new chip-and-saw machine developed in Shelton, Washington, and manufactured in Vancouver, B.C. has two functions. A log is fed in one end and lumber and chips come out the other. Another machine designed in British Columbia has similar objectives where logs are chipped down to square cants before going through a sash gang.

Small logs are well suited to automation and it is probably along these lines that the successful small $\log$ mills will develop. Accuracy of sawing and quality of product are important when cutting logs of any size but when cutting small logs their importance cannot be over-stressed. With the development of pulp mills in the interior the quantity of chips produced from small logs should be an important factor in the development of small $\log$ sawmills.

\section{BiBLIOGRAPHY}

DOYLE, J. A. Small Logs and the Production of Spruce Lumber. Timber of Canada, April, 1960. McBRIDE, C. F. Factors Affecting Lumber Recovery from Spruce in the Prince George Area. Mimeo V-1020. F.P.R.B. 1956. 